\title{
ANALISIS TINGKAT KEPUASAN KERJA KARYAWAN PADA PT. ANUGERAH FITRAH HIDAYAH MAKASSAR
}

\author{
Afiah Mukhtar*) \\ Dosen STIE TriDharma Nusantara \\ E-mail: afiah.muhtar@gmail.com
}

\begin{abstract}
Abstrak
Penelitian ini bertujuan untuk mengetahui tingkat kepuasan kerja karyawan pada PT. Anugerah Fitrah Hidayah Makassar.Jenis data yang digunakan pada penelitian ini adalah data kualitatif dan kuantitatif, sedangkansumber data yang digunakan yaitu data primer dan sekunder. Populasi yang digunakan adalah seluruh karyawan yang bekerja pada PT. Anugerah Fitrah Hidayah makassardengansampel berjumlah 50 orang. Sedangkan Metode yang digunakan adalah metode deskriptifyaitu analisis skala likert dengan mendiskripsikan tingkat kepuasan kerja karyawan berdasarkan hasil yang telah diperoleh dengan interval 61\%-80\% tergolong dalam kriteriatinggi.
\end{abstract}

Kata Kunci: Kepuasan Kerja

\begin{abstract}
This study aims to determine the level of employee job satisfaction at PT. Anugerah Fitrah Hidayah Makassar. The types of data used in this study are qualitative and quantitative data, while the data sources used are primary and secondary data. The population used is all employees who work at PT. Anugerah Fitrah Hidayah Makassar with a sample of 50 people. While the method used is a descriptive method of Likert scale analysis by describing the level of employee job satisfaction based on the results obtained at intervals of $61 \%-80 \%$ classified as high criteria.
\end{abstract}

Keywords:Job satisfaction

\section{PENDAHULUAN}

Era globalisasi saat ini, karyawan dipandang sebagai salah satu aset perusahaan yang penting dan perlu dikelola serta dikembangkan untuk mendukung kelangsungan hidup perusahan. perusahan juga dihadapkan pada tantangan besar untuk memenangkan persaingan, sehingga dibutuhkan kesiapan yang matang untuk menghadapi era globalisasi.

Dalam pemilihan taktik dan strategi, perusahaan memerlukan analisis perubahan lingkungan eksternal seperti demogratif, sosial budaya, politik, teknologi dan persaigan, serta menganalisis faktor internal perusahaan seperti kekuatan dan kelemahan perusahaan dalam usaha meraih sasaran yang ditetapkan.

Banyak faktor yang perlu mendapat perhatian dalam menganalisis kepuasan kerja seseorang. Misalnya, sifat pekerjaan seseorang mempunyai dampak tertentu pada kepuasan kerja. Berbagai penelitian telah membuktikan bahwa apabila dalam pekerjaan seseorang mempunyai otonomi untuk bertindak, terdapat variasi, memberikan sumbangan penting dalam keberhasilan organisasi dan karyawan memperoleh umpan balik tentang hasil pekerjaan yang dilakukannya, yang bersangkutan akan merasa puas. Bentuk program perkenalan yang tepat serta berakibat pada diterimanya seseorang sebagai anggota kelompok kerja dan oleh organisasi secara ikhlas dan terhormat juga pada umumnya berakibat pada tingkat kepuasan kerja yang tinggi.

Kepuasan kerja juga berhubungan dengan jenis pekerjaan yang dimiliki, aspek lingkungan kerja seperti kepemimpinan, 
keadaan ruangan, kompensasi, interaksi sosial sesama karyawan, dan pengembangan karir pun berhubungan erat dengan kepuasan kerja karyawan. Semakin nyaman dan aman kondisi lingkungan kerja, semakin tinggi pula kepuasan kerja karyawan. Dan ini merupakan salah satu langkah dalam meningkatkan motivasi kerja.

Dalam hal ini, salah satu cara yang dapat memotivasi peningkatan prestasi kerja karyawan adalah pemberian kompensasi pada pengupahan dan kondisi kerja yang baik. Kompensasi tersebut sangat penting bagi karyawan itu sendiri sebagai individu, karena besarnya kompensasi pengubahan dan kondisi kerja merupakan pencerminan atau ukuran nilai pekerjaan karyawan itu sendiri. Sebaliknya, besar kecilnya kompensasi tersebut dapat mempengaruhi prestasi kerja karyawan apabila kompensasinya dapat diberikan secara tepat dan benar, maka karyawan akan memperoleh kepuasan kerja dan termotivasi untuk mencapai tujuan-tujuan perusahaan.

Kepuasan kerja karyawan merupakan faktor yang dapat mendorong dan mempengaruhi semagat kerja. Kepuasan kerja pada dasarnya merupakan hal yang bersifat individual. Seperti individu memiliki tingkat kepuasan yang berbedabeda sesuai dengan keinginan dan sistem nilai yang dianutnya.

Kepuasan kerja karyawan berkaitan dengan aspek keadilan dan kelayakan akan balas jasa yang diterima karyawan atas kinerjanya yang disumbangkan untuk perusahaan. Apabila aspek keadilan dan kelayakan bagi karyawan dapat dirumuskan dengan baik, maka keryawan akan merasa puas, mempunyai semagat kerja yang tinggi yang nantinya dapat meningkatkan pelayanan prima kepada pelanggan. Apabila rasa keadilan dan kelayakan ini tidak terpenuhi maka akan menimbulkan perasaan yang tidak puas pada karyawan, perasaan tidak puas ini justru akan menyebabkan terjadinya kemerosotan semangat kerja karyawan yang pada akhirnya akan menyebabkan turunnya kualitas pelayanan yang akan diberikan karyawan kepada para pelanggan.

$\begin{array}{ccr}\text { Karyawan } & \text { yang mendapatkan } \\ \text { kepuasan kerja akan melaksanakan }\end{array}$ pekerjaan dengan lebih baik, karyawan yang tidak memperoleh kepuasan kerja tidak akan pernah mencapai kematangan psikologi yang akan menyebabkan frustasi. Karyawan seperti ini akan sering melamun, semagat kerja yang rendah, cepat bosan dan lelah, emosi tidak stabil, sering absen dan melakukan kesibukan yang tidak ada hubuganya dengan pekerjaan yang harus dilakukan. Kepuasan yang tinggi akan mengarahkan pada tingkat turn over dan absensi yang rendah kerena individu yang puas terdorong untuk bekerja lebih baik.

Ketika seorang karyawan merasakan kepuasan dalam bekerja maka seorang karyawan akan berupaya semaksimal mungkin menyelesaikan pekerjaanya, yang akhirnya akan menghasilkan kualitas pelayanan yang tinggi dan pencapaian tujuan perusahaan.

\section{Rumusan masalah}

Berdasarkan uraian latar belakang yang telah dikemukakan sebelumnya maka rumusan masalah dalam penelitian ini adalah "Bagaimanakah tingkat kepuasan kerja keryawan pada PT. Anugerah Fitrah Hidayah Makassar".

\section{Tujuan dan Manfaat Penelitian}

Adapun tujuan yang ingin dicapai dari penelitian adalah untuk mengetahui tingkat kepuasan kerja karyawan pada PT. Anugerah Fitrah Hidayah Makassar

Adapun manfaat dari penelitian ini adalah sebagai berikut:

1. Sebagai bahan referensi bagi pengembangan ilmu pengetahuan khususnya dalam tingkat kepuasan kerja 
karyawan pada PT. Anugerah Fitrah Hidayah Makassar

2. Sebagai bahan referensi atau rujukan bagi peneliti para karyawan terutama pada PT. Anugerah Fitrah Hidayah Makassar

\section{Tinjauan Pustaka}

\section{A. Pengertian Kepuasan Kerja}

Menurut Sunyoto (2013:210), kepuasan kerja (job satisfaction) adalah keadaan emosional yang menyenangkan atau tidak menyenangkan dimana para karyawan memandang pekerjaannya. Kepuasan kerja mencerminkan perasaan seseorang terhadap pekerjaanya.

Menurut Herman dan Iwa (2007:90) kepuasan kerja adalah sikap untuk seseorang dalam menghadapi pekerjaannya, seseorang yang tinggi kepuasan kerjanya memiliki sikap yang positif terhadap pekerjaannya, sedangkan seseorang yang tidak memperoleh kepuasan didalam pekerjaannya memiliki sikap yang negatif terhadap pekerjaannya.

Menurut Robbins (2001:179) kepuasan kerja adalah suatu sikap umum seseorang individu terhadap pekerjaannya.

Menurut Hasibuan

kepuasan kerja adalah sikap emosional yang menyenangkan dan mencintai pekerjaannya. Sikap ini dicerminkan oleh moral kerja, kedisiplinan dan prestasi kerja. Kepuasan kerja dinikmati dalam pekerjaan luar pekerjaan dan kombinasi dalam dan luar pekerjaan.

Menurut Kreitner dan Kinicki (2005:271) kepuasan kerja adalah suatu efektivitas atau responden emosional terdapat berbagai aspek pekerjaan.

Menurut Martoyo (2000:142) kepuasan kerja adalah keadaan emosional karyawan dimana terjadi ataupun tidak terjadi titik temu antara nilai balas jasa kerja karyawan dari perusahaan/organisasi dengan tingkat nilai balas jasa yang memang diiginkan oleh karyawan yang bersangkutan.

Pada dasarnya kepuasan kerja merupakan hal yang bersifat individu. Setiap individu memiliki tingkat kepuasan yang berbeda-beda sesuai dengan sistem nilainilai yang berlaku pada dirinya. Ini disebabkan karena adanya perbedaan pada masing-masing individu. Semakin banyak aspek-aspek dalam pekerjaan yang sesuai dengan keinginan individu tersebut, maka semakin tinggi tingkat kepuasan yang dirasakannya, sebaliknya semakin sedikit aspek-aspek dalam pekerjaan yang sesuai dengan keinginan individu.

Dari beberapa pengertian kepuasan kerja diatas, penulis dapat mengambil kesimpulan bahwa keputusan kerja adalah hasil akhir yang pasti diiginkan seseorang terhadap pekerjaannya dan kepuasan bukan merupakan konsep tunggal, dalam hal ini seseorang dapat relatif puas dengan salah satu aspek pekerjaan dan tidak puas dengan satu atau lebih aspek lainnya.

\section{A. Faktor-faktor yang Mempengaruhi Kepuasan Kerja}

Menurut Ghiselli dan Brown dalam Sunyoto (2013:212-213), faktor-faktor yang mempengaruhi kepuasan kerja, yaitu:

Tentang faktor-faktor yang menimbulkan kepuasan kerja terhadap karyawan, yaitu:

1. Kedudukan

Orang beranggapan bahwa seseorang yang bekerja pada pekerjaan yang lebih tinggi akan merasa lebih puas dari pada yang berkedudukan lebih rendah.

2. Pangkat

Pada pekerjaan yang mendasar pada perbedaan tingkat golongan, sehingga pekerjaan tersebut memberikan kedudukan tertentu pada setiap orang yang melakukan nya. Jika ada kenaikan upah, maka 
ada yang beranggapan sebagai kenaikan pangkat.

3. Umur

Dinyatakan adanya hubungan antara kepuasan kerja dengan umur karyawan . umur 25 tahun sampai 34 tahun dan umur 40 sampai 45 tahun adalah umur yang biasa menimbulkan perasaan kurang puas terhadap pekerjaannya.

4. Mutu pengawasan

Kepuasan karyawan dapat ditingkatkan melalui perhatian dan hubungan yang baik dari pimpinan dan hubungan yang lebih baik dapat pimpinan dan bawahan sehingga karyawan akan merasa bahwa dirinya merupakan bagian yang terpenting dari organisasi kerja tersebut.

Dari beberapa pendapat di atas menurut Brown dan Ghilelli dalam Sutrisno (2009:80), faktor-faktor yang mempengaruhi kepuasan kerja adalah :

1. Faktor psikologi, merupakan faktor yang berhubungan dengan kejiwaan karyawan meliputi minat, ketentraman dalam bekerja, sikap terhadap kerja, bakat dan keterampilan.

2. Faktor sosial, merupakan faktor yang berhubungan dengan interaksi sosial baik sesama karyawan, maupun kepada pimpinan.

3. Faktor fisik, merupakan faktor yang berhubungan dengan kondisi fisik lingkungan kerja dan kondisi fisik karyawan, jenis pekerjaan, pengaturan waktu kerja dan waktu istrahat, perlengkapan kerja, keadaan ruangan, suhu, penerangan, perputaran udara dan kondisi kesehatan karyawan.

4. Faktor financial, merupakan faktor yang berhubungan dengan jaminan serta kesejahteraan karyawan yang meliputi sistem dan besarnya gaji, jaminan sosial, berbagai tunjangan, fasilitas yang diberikan promosi dan sebagainya.

Menurut As'ad ( 2004:112-115) faktor-faktor yang mempengaruhi kepuasan kerja adalah :

1. Faktor utama dalam pekerjaan meliputi upah, ketentraman, kondisi kerja dan kesempatan untuk maju. Selain itu juga penghargaan terhadap kecakapan, hubungan sosial didalam pekerjaan, ketepatan dalam menyelesaikan komflik antar manusia, perasaan diperlukan adil dan baik yang menyangkut pribadi maupun tugas.

2. Mutu pengawasan

Hubungan antara karyawan daengan pihak pimpinan sangat penting artinya dalam menaikan produktivitas kerja. Kepuasan karyawan dapat ditingkatkan melalui perhatian dan hubungan yang baik dari pimpinan kepada bawahan, sehingga karyawan akan merasa bahwa dirinya merupakan bagian yang penting dari organisasi kerja.

3. Fasilitas

Fasilitas rumah sakit, cuti, dana pensiun, atau perumahan merupakan standar suatu jabatan dan apabila dapat dipenuhi akan menimbulkan rasa puas.

4. Pendidikan (training, up grading dan sebagainya)

Beberapa faktor yang mempengaruhi tingkat kepuasan kerja menurut para ahli diatas pada prinsipnya adalah faktor-faktor yang ditujukan kepada kepentingan karyawan. Hal ini sebagai bukti, bahwa masalah sumber daya manusia adalah suatu yang harus dikedepankan jika perusahaan menginginkan aktivitas kerja berjalan dengan baik, karena 
baik tidaknya dan berhasil tidaknya perusahaan dalam mewujudkan tujuan yang hendak dicapai sangat bergantung dari kualitas sumber daya manusia yang dimiliki perusahaan bersangkutan dan kepuasan kerja merupakan variabel yang menjadi sasaran dan tujuan dari pelaksanaan pengembangan sumber daya manusia yang dilaksanakan perusahaan. Sedangkan faktor-faktor yang mempengaruhi kepuasan kerja.

Banyak faktor yang mempengaruhi kepuasan kerja karyawan. Faktor-faktor itu sendiri dalam perananya memberikan kepuasan kepada karyawan bergantung pada pribadi masing-masing karyawan. Faktorfaktor yang memberikan kepuasan menurut Blum dalam Sutrisno (2009:77), adalah:

1. Faktor individual, meliputi umur, kesehatan, watak, dan harapan.

2. Faktor sosial, meliputi hubungan kekeluargaan, pendangan pekerja, kebebasan berpolitik, dan hubungan kemasyarakatan.

3. Faktor utama dalam pekerjaan, meliputi upah, pengawasan, ketenteraman kerja, kondisi kerja, dan kesempatan untuk maju. Selain itu, juga penghargaan terhadap kecakapan, hubungan sosial didalam pekerjaan, ketepatan dalam menyelesaikan konflik antara manusia, perasaan diperlakukan adil baik yang menyangkut pribadi maupun tugas.

Faktor-faktor yang biasanya digunakan untuk mengukur kepuasan kerja seorang karyawan adalah:

Menurut Gilmer dalam Sutrisno (2009:77-78), faktor-faktor yang mempengaruhi kepuasan kerja adalah:

1. Kesempatan untuk maju

Dalam hal ini ada tidaknya kesempatan untuk memperoleh pengalaman dan peningkatan kemampuan selama kerja.

2. Keamanan kerja

Faktor ini disebut sebagai penunjang kepuasan kerja, baik bagi karyawan. Keadaan yang aman sangat memengaruhi perasaan karyawan selama kerja.

3. Gaji, gaji lebih banyak menyebabkan ketidak puasan, dan jarang orang mengekspresikan kepuasan kerjanya dengan sejumlah uang yang diperolehnya.

4. Perusahaan dan manajemen

Perusahaan dan manajemen yang baik adalah yang mampu memperikan situasi dan kondisi kerja yang stabil. Faktor ini yang menentukan kepuasan kerja karyawan.

5. Pengawasan, sekaligus atasanya. Supervise yang buruk dapat berkibat absensi dan turn over.

6. Faktor instrinsik dari pekerjaan, atribut yang ada dalam pekerjaan mensyaratkan keterampilan tertentu. Sukar dan mudahnya serta kebanggan akan tugas dapat meningkatkan atau mengurangi kepuasan.

7. Kondisi kerja

Termasuk disini kondisi tempat, ventilasi, penyiaran, kantin, dan tempat parker.

8. Aspek sosisl dalam pekerjaan

Merupakan salah satu sikap yang sulik digambarkan tetapi dipandang sebagai faktor yang menunjang puas atau tidak puas dalam kerja.

9. Komunikasi

Komunikasi yang lancar antar karyawan dengan pihak manajemen banyak dipakai alasan untuk menyukai jabatanya. Dalam hal ini adanya kesediaan pihak atasan untuk mendengar, memahami, dan megakui 
pendapatan ataupun prestasi karyawanya.

10. Fasilitas

Fasilitas rumah sakit, cuti, dana pensiun, atau perumahan merupakan standar suatu jabatan dan apabila dapat dipenuhi akan menimbulkan rasa puas.

\section{B. Teori Kepuasan Kerja}

Menurut Wexley dan Yuki dalam Sunyoto (2013:211), teori kepuasan kerja ada tiga macam yaitu sebagai berikut:

1. Teori ketidaksesuaian.

Kepuasan atau ketidak puasan dengan sejumlah aspek pekerjaan tergantung pada selisih antara apa yang dianggap telah didapatkan dengan apa yang diinginkan dari karakteristik pekerjaan didefinisikan sebagai jumlah minimum yang diperlukan untuk memenuhi kebutuhan yang ada. Seseorang akan terpuaskan untuk memenuhi kebutuhan yang ada. Seseorang akan terpuaskan jika tidak ada selisih antara kondisi-kondisi yang telah dialami. Semakin besar kekurangan dan semakin banyak hal-hal penting yang diiginkan, semakin besar ketidak puasannya.

2. Teori keadilan

Teori keadilan memerinci kondisikondisi yang mendasari seorang pekerja akan mengangap fair dan masuk akal insentif dan keuntungan dalam pekerjaannya. Komponen utama dari teori ini adalah input, hasil, keadilan atau ketidakadilan.

3. Teori dua faktor

Teori ini menyatakan bahwa kepuasan kerja secara kualitatif berbeda dengan ketidakpuasan kerja. Menurut teori ini, karakteristik pekerjaan dapat dikelompokan menjadi dua kategori yaitu "disatisfiers/ hygiene factors" dan "satisfiers atau motivators" Hygiene factors meliputi hal-hal seperti: gaji/upah, pengawasan, hubungan antar pribadi, kondisi kerja dan status.

Menurut Rivai dan Sagala (2009:856857), ada tiga macam teori tentang kepuasan kerja yang cukup dikenal adalah:

1. Teori Ketidaksesuaian (Discrepancy theory)

Teori ini mengukur kepuasan kerja seseorang dengan menghitung selisih antara sesuatu yang seharusnya dengan kenyataan yang dirasakan . sehingga apabila kepuasannya diperoleh melebihi dari yang diinginkan, maka orang akan menjadi lebih puas lagi, sehingga terdapat discrepancy, tetapi merupakan discrepancy yang positif. Kepuasan kerja seseorang tergantung pada selisih antara sesuatu yang dianggap akan didapatkan dengan apa yang dicapai.

2. Teori Keadilan (Equity theory)

Teori ini mengemukakan bahwa orang akan merasa puas atau tidak puas, tergantung pada ada atau tidaknya keadilan (equity) dalam suatu situasi, khususnya situasi kerja. Menurut teori ini komponen utama dalam teori keadilan adalah input, hasil, keadilan dan ketidakadilan. Input adalah faktor bernilai bagi karyawan yang dianggap mendukung pekerjaannya, seperti pendidikan, pengalaman, kecakapan, jumlah tugas dan peralatan atau perlengkapan yang dipergunakan untuk melaksanakan pekerjaannya. Hasilnya adalah sesuatu yang dianggap bernilai oleh seseorang karyawan yang diperoleh dari pekerjaannya, seperti: upah/gaji, keuntungan sampingan, symbol, status, penghargaan dan kesempatan 
untuk berhasil atau aktualisasi diri. Sedangkan orang selalu membandingkan dapat beberupa seseorang diperusahaan yang sama, atau ditempat lain atau bisa pula dengan dirinya dimasa lalu. Menurut teori ini, setiap karyawan akan membandingkan rasio input hasil dirinya deengan rasio input hasil orang lain. Bila perbandingan ini dianggap cukup adil, maka karyawan akan merasa puas. Bila perbandingan itu tidak seimbang tetapi menguntungkan bisa menimbulkan kepuasan, tetapi bisa pula tidak. Tetapi bila perbandingan itu tidak seimbang akan timbul ketidakpuasan.

3. Teori dua faktor (Two factor theory) Menurut teori ini kepuasan kerja dan ketidakpuasan kerja itu merupakan hal yang berbeda. Kepuasan dan ketidakpuasan terhadap pekerjaan itu bukan suatu variabel yang kontinu. Teori ini merumuskan karakteristik pekerjaan menjadi dua kelompok yaitu yaitu satisfies atau motivator dan dissatisfies. Satisfies ialah faktor-faktor atau situasi yang dibutuhkan sebagai sumber kepuasan kerja yang terdiri dari: pekerjaan yang menarik, penuh tantangan, ada kesempatan berprestasi, kesempatan memperoleh penghargaan dan promosi. Terpenuhinya faktor tersebut akan menimbulkan kepuasan, namun tidak terpenuhinya faktor ini tidak selalu mengakibatkan ketidakpuasan. Dissatisfies (hygiene factors) adalah faktor-faktor yang menjadi sumber ketidakpuasan yang terdiri dari: gaji/upah, pengawasan, hubungan antarpribadi, kondisi kerja dan status. Faktor ini diperlukan untuk memenuhi dorongan biologis serta kebutuhan dasar karyawan. Jika tidak terpenuhi faktor ini, karyawan tidak akan puas. Namun, jika besarnya faktor ini memadai untuk memenuhi kebutuhan tersebut, karyawan tidak akan kecewa meskipun belum terpuaskan.

\section{Hal-hal Penting Dalam Kepuasan Kerja}

Menurut Robbins dalam Sutrisno (2009:75), hal-hal pentiing dalam kepuasan kerja dalam organisasi sekurang-kurangnya dengan 3 (tiga) alasan adalah:

1. Ada bukti yang jelas bahwa karyawan yang tidak puas lebih sering melewatkan kerja dan lebih besar kemungkinan mengundurkan diri.

2. Telah diperagakan bahwa karyawan yang puas mempunyai kesehatan yang lebih baik dan usia lebih panjang.

3. Kepuasan pada pekerjaan.

Menurut Herman dan Iwa (2007:92) hal-hal penting dalam kepuasan kerja adalah:

1. Pekerjaan yang menantang yaitu pekerjaan yang memberikan kesempatan untuk memanfaatkan segala kemampuan, keterampilan dan menewarkan berbagai tugas, kebebasan serta masukan tentang seberapa baik hasil pekerjaan.

2. Imbalan yang wajar/jasa diterima yaitu upah yang sesuai dengan banyaknya permintaan kerja, tingkat keterampilan individual, standar upah yang berlaku dimasyarakat.

3. Syarat-syarat kerja yang mendukung yaitu fasilitas-fasilitas kerja yang mendukung untuk memperlancar pekerjaan.

4. Kolega-kolega kerja yang mendukung yaitu dapat terjadi kerjasama yang baik antara sesame pekerja baik didalam maupun diluar lingkungan kerja. 


\section{Cara Meningkatkan Kepuasan Kerja \\ Apakah kepuasan kerja dapat} ditingkatkan atau tidak, tergantung dari apakah imbalan sesuai dengan ekspektasi, kebutuhan dan keinginan karyawan. Jika kinerja yang lebih baik dapat meningkatkan imbalan bagi karyawan secara adil dan seimbang, maka kepuasan kerja akan maningkat. Dalam kasus lain, kepuasan karyawan merupakan umpan balik yang mempengaruhi self-image dan motivasi untuk meningkatkan kinerja.

Menurut Riggio dalam Sutrisno (2009:87), cara meningkatkan kepuasan kerja dapat dilakukan dengan cara sebagai berikut:

1. Melakukan perubahan struktur kerja Misalnya dengan melakukan perputaran pekerjaan (job rotation), yaitu sebuah sistem perubahan pekerjaan dari salah satu tipe tugas ketugas yang lainnya (yang disesuaikan dengan job description). Cara kedua yang harus dilakukan adalah dengan pemekaran (job enlargement), atau perluasan satu pekerjaan sebagai tambahan dan bermacam-macam tugas pekerjaan. Praktik untuk para pekerja yang menerima tugas-tugas tambahan dan bervariasi dalam usaha untuk membuat mereka merasakan bahwa mereka adalah lebih dari sekedar anggotadari organisasi.

2. Melakukan perubahan struktur pembayaran

Perubahan sistem pembayaran ini dilakukan dengan berdasarkan pada keahliannya (skill-based pay), yaitu pembayaran dimana para pekerja digaji berdasarkan pengetahuan dan keterampilannya dari pada posisinya diperusahaan. Pembayaran kedua dilakukan berdasarkan jasanya (merit pay), sistem pembayaran dimana pekerja digaji berdasarkan performancenya, pencapaian financial pekerja berdasarkan pada hasil yang dicapai oleh individu itu sendiri. Pembayaran yang ketiga adalah Gainsharing atau pembayaran berdasarkan pada keberhasilan kelompok (keuntungan dibagi kepada seluruh anggota kelompok).

3. Pemberian jadwal kerja yang fleksibel

Dengan memberikan control pada para pekerja mengenai pekerjaan sehari-hari mereka, yang sangat penting untuk mereka yang bekerja di daerah padat, dimana pekerja tidak bisa bekerja tepat waktu atau untuk mereka yang mempunyai tanggung jawab pada anak-anak. Compressed work week (pekerjaanmingguan yang dipadatkan), dimana jumlah pekerjaan per harinya dikurangi sedang jumlah jam pekerjaan per hari ditingkatkan. Para pekerja dapat memadatkan pekerjaannya yang hanya dilakukan dari hari Senin hingga Jum'at, sehingga mereka dapat memiliki waktu longgaruntukliburan. Cara yang kedua adalah dengan sistem penjadwalan dimana seorang pekerja menjalankan sejumlah jam khusus per minggu (Flextime), tetapi tetap mempunyai fleksibilitas kapan mulai dan mengakhiri pekerjaannya.

4. Mengadakan program yang mendukung, perusahaan mengadakan program-program yang dirasakan dapat meningkatkan kepuasan kerja para karyawan, seperti; health center, profit sharing, dan employee sponsored child care.

\section{METODE PENELITIAN}

\section{A. Tempat dan Waktu Penelitian}

Penelitian ini dilakukan pada PT. Anugerah Fitrah Hidayah Makassar yang beralamat di 
Jalan Kima 08 Kav UU.4 Makassar. Waktu penelitian dilaksanakan selama kurang lebih 2 (dua) bulan, yaitu sejak awal bulan Juni sampai dengan akhir Juli 2019.

B. Jenis dan Sumber Data

1. Jenis Data

Adapun data yang digunakan dalam penulisan ini adalah :

a. Data Kualitatif,

b. Data kuantitatif

2. Sumber Data

Untuk memperoleh data yang diperlukan dalam penulisan ini diperoleh dari sumber-sumber sebagai berikut :

a. Data Primer yaitu data yang diperoleh dengan jalan mengadakan wawancara secara langsung dengan pimpinan, sejumlah karyawan dan data yang diperoleh secara langsung pada objek penelitian tersebut.

b. Data Sekunder yaitu data yang diperoleh dari perusahaan atau tempat penelitian dengan jalan mengumpulkan dokumen-dokumen berupa keadaan dan perkembangan karyawan dan kita sisa memindahkanya.

\section{Metode Pengumpulan Data}

Adapun metode yang digunakan dalam pengumpulan data dalam penulisan ini diperoleh dari :

1. Penelitian Pustaka (Library Research)

2. Penelitian Lapangan (Field Research) Ini dilakukan dengan 4 (empat) tahap, yaitu :
a. Observasi.
b. Wawancara
c. Dokumentasi
d. Kuesioner.

\section{Populasi dan Sampel}

1. Populasi

Dalam penelitian ini yang menjadi populasi adalah seluruh karyawan PT. Anugerah Fitrah Hidayah Makassar yang berjumlah 55 orang karyawan.
2. Sampel

Penelitian ini penulis mengambil sampel berdasarkan jumlah seluruh karyawan yang bekerja pada PT. Anugerah Fitrah Hidayah Makassar berjumlah 55 orang namun responden yang dapat ditemui hanya 50 orang, sehingga sampel dalam penelitian ini berjumlah 50 orang.

\section{E. Metode Analisis}

Metode analisis yang digunakan dalam penelitian ini yaitu metode analisis deskriptif, merupakan suatu metode yang dipergunakan untuk menjelaskan analisis tingkat kepuasan kerja karyawan pada PT. Anugerah Fitrah Hidayah Makassar

Berdasarkan hasil kuisioner yang diberikan kepada responden kemudian skor hasil perolehan kuisioner diolah.

Adapun langkah-langkah dalam melakukan analisis ini adalah sebagai berikut:

1. Setiap indikator yang dinilai oleh responden diklasifikasikan ke dalam 5 alternatif jawaban yang diberi skor antara 1 sampai dengan 5 .

2. Dihitung total skor $=$ jumlah skor dari seluruh skor indikator untuk semua koresponden.

3. Dihitung skor.

4. Untuk mendiskripsikan jawaban responden juga digunakan statistik dieskriptif seperti distribusi frekuensi dan ditampilkan dalam tabel.

Untuk menjawab tentang analisis variabel penelitian digunakan rentang kriteria penilaian. Selanjutnya untuk menetapkan peringkat dalam variabel penelitian dapat dilihat dari perbandingan antara skor aktual dengan skor ideal. Skor aktual diperoleh melalui hasil perhitungan seluruh pendapat responden sesuai klasifikasi bobot yang diberikan. Sedangkan skor ideal diperoleh melalui perolehan 
prediksi nilai tertinggi dikalikan dengan jumlah kuisioner dikalikan jumlah koresponden.

Adapun urutan skor yang diberikan menggunakan skala likert menurut Sugiyono (2012:137) adalah sebagai berikut:

a. Sangat puas diberi bobot: 5

b. Puas diberi bobot: 4

c. Cukup puas diberi bobot: 3

d. Tidak puas diberi bobot: 2

e. Sangat tidak puas diberi bobot : 1

Untuk pilihan variabel terdiri dari 5 dimensi (bobot) dengan 17 item kuisioner dengan jumlah responden sebanyak 50 orang, maka diperoleh kriteria yaitu sebagai berikut:
Skor aktual : Jawaban seluruh responden (50) orang atas 17 kuisioner yang diajukan.

Skor ideal : Bobot tertinggi dikalikan dengan jumlah sampel yaitu 5 $\times 50=250$.

$\%$ Skor ideal: Skor aktual dibagi skor ideal dikali $100 \%$.

Dari hasil uraian tersebut di atas, maka dikonversi dengan kriteria interpretasi skor yang telah ditetapkan dalam interval penilaian pada tabel 1 yang dikemukakan oleh Sugiyono (2012:144), yaitu sebagai berikut:

Tabel 1. Interval skor ideal dan skor aktual.

\begin{tabular}{|c|c|}
\hline $\begin{array}{c}\text { Interval } \\
(\mathbf{\%})\end{array}$ & Kreteria \\
\hline $0-20$ & Sangat Rendah \\
\hline $21-40$ & Rendah \\
\hline $41-60$ & Sedang \\
\hline $61-80$ & Tinggi \\
\hline $81-100$ & Sangat tinggi \\
\hline
\end{tabular}

Sumber: Sugiyono $(2012: 144)$

HASIL PENELITIAN DAN untuk memberikan gambaran mengenai PEMBAHASAN

indentitas responden yang menjadi sampel

A. Karakteristik Responden

Kemudian dalam penelitian ini,karakteristik responden dapat dikelompokkan atas: jenis kelamin, umur, status perkawinan, pendidikan terakhir dan masa kerja. Salah satu tujuan dengan menguraikan karakteristik responden adalah dalam penelitian ini.

Dalam kaitannya dengan uraian tersebut diatas, dapat disajikan karakteristik responden menurut jenis kelamin, umur, pendidikan terakhir dan masa kerja yang dapat diuraikan serta dijelaskan sebagai berikut:

1. Jenis Kelamin

Tabel 2. Jumlah responden menurut jenis kelamin

\begin{tabular}{|c|c|c|c|}
\hline \multirow{2}{*}{ No. } & \multirow{2}{*}{ Jenis Kelamin } & \multicolumn{2}{|c|}{ Jumlah } \\
\cline { 3 - 4 } & Laki-laki & 50 & 100 \\
\hline \multicolumn{2}{|c|}{ Total } & 50 & $100 \%$ \\
\hline
\end{tabular}

Sumber: Data diolah, 2019 
Karyawan PT. Anugerah Fitrah Hidayah Makassar hanya mempekerjakan karyawan laki-laki karena bentuk pekerjaan yang dibutuhkan bergerak dibidang Jual dan Rental Scaffolding.

2. Umur
Umur responden merupakan tingkatan umur responden yang menjadi sampel dalam penelitian ini, sehingga pengelompokkan umur responden dapat dikelompokkan menjadi 2 kelompok yang dapat disajikan melalui tabel berikut ini:

Tabel 3. Jumlah responden menurut umur

\begin{tabular}{|c|c|c|c|}
\hline \multirow{2}{*}{ No. } & \multirow{2}{*}{$\begin{array}{c}\text { Umur } \\
\text { (Tahun) }\end{array}$} & Orang & $\%$ \\
\cline { 2 - 4 } & $19-24$ & 25 & 50 \\
\hline 2 & $24-29$ & 18 & 36 \\
\hline 3 & $29-34$ & 5 & 10 \\
\hline 4 & $34-38$ & 2 & 4 \\
\hline & Total & 50 & $100 \%$ \\
\hline
\end{tabular}

Sumber: Data diolah, 2019

3. Pendidikan Terakhir

Jenis pendidikan terakhir responden menjelaskan latar belakang pendidikan responden yang menjadi sampel dalam penelitian ini, sehingga dalam penelitian ini maka tingkat pendidikan responden dapat diklasifikasikan menurut jenjang pendidikan pada tabel berikut ini:

Tabel 4. Jumlah responden menurut pendidikan terakhir

\begin{tabular}{|c|l|c|c|}
\hline \multirow{2}{*}{ No. } & \multicolumn{2}{|c|}{ Pendidikan Terakhir } & \multicolumn{2}{|c|}{ Jumlah } \\
\cline { 3 - 4 } & & Orang & $\%$ \\
\hline 1 & SLTA & 40 & 80 \\
\hline 2 & Sarjana & 10 & 20 \\
\hline \multicolumn{2}{|c|}{ Total } & 50 & $100 \%$ \\
\hline
\end{tabular}

Sumber: Data diolah, 2019

4. Masa Kerja

Masa kerja karyawan merupakan masa lama mereka mengabdikan dirinya dalam perusahaan dan berusaha memberikan yang terbaik.

Tabel 5. Jumlah responden menurut masa kerja

\begin{tabular}{|c|c|c|c|}
\hline \multirow{2}{*}{ No. } & \multirow{2}{*}{$\begin{array}{c}\text { Masa Kerja } \\
\text { (Tahun) }\end{array}$} & Orang & $\%$ \\
\cline { 2 - 4 } & $1-2$ & 22 & 44 \\
\hline
\end{tabular}




\begin{tabular}{|c|c|c|c|}
\hline 2 & $2-3$ & 12 & 24 \\
\hline 3 & $3-4$ & 6 & 12 \\
\hline 4 & $4-5$ & 10 & 20 \\
\hline & Total & 50 & $100 \%$ \\
\hline
\end{tabular}

Sumber: Data diolah, 2019

B. Analisis Tingkat Kepuasan Kerja Karyawan

Kepuasan kerja adalah suatu yang timpul dari seseorang yang biasanya ditunjukan dengan sikap dan prilaku positif diakibatkan terpenuhinya kebutuhan, keinginan, dan kepuasan yang datang dari diri kita sendiri dapat berupa materi dan juga tidak.

Tabel 6. Analisis tingkat kepuasan kerja karyawan pada PT. Anugerah Fitrah Hidayah Makassar".

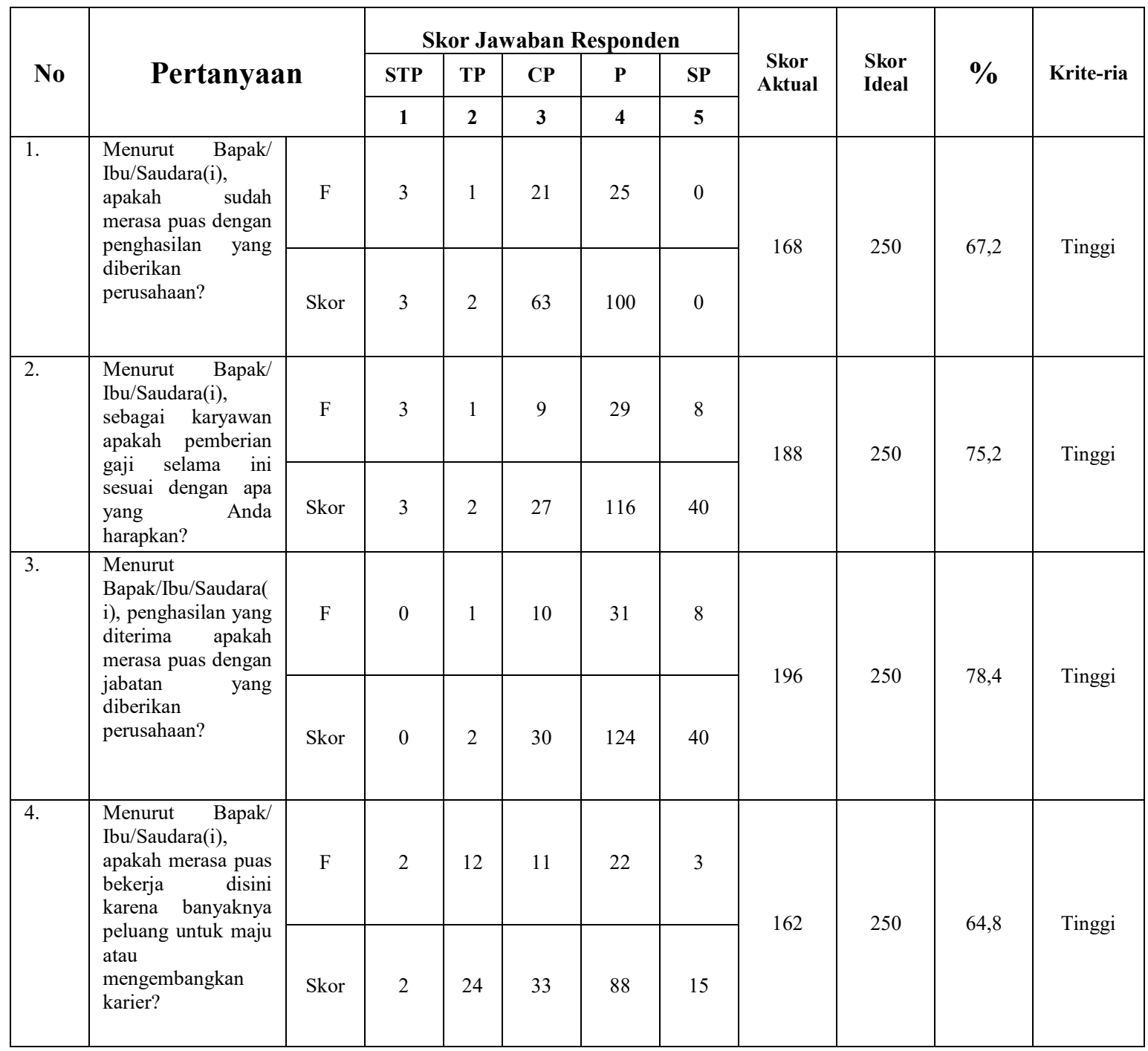




\begin{tabular}{|c|c|c|c|c|c|c|c|c|c|c|c|}
\hline 5. & $\begin{array}{lr}\text { Menurut } & \text { Bapak/ } \\
\text { Ibu/Saudara (i), } \\
\text { sebagai karyawan } \\
\text { mempunyai } \\
\text { persaingan yang } \\
\text { sehat antara rekan } \\
\text { kerja Anda? }\end{array}$ & Skor & 1 & 14 & 39 & 108 & 10 & 172 & 250 & 68,8 & Tinggi \\
\hline 6. & $\begin{array}{l}\text { Menurut Bapak/ } \\
\text { Ibu/Saudara(i), } \\
\text { sebagai karyawan } \\
\text { merasa puas dengan } \\
\text { perlengkapan yang } \\
\text { ada dikantor? }\end{array}$ & Skor & 0 & 14 & 27 & 108 & 35 & 184 & 250 & 73,6 & Tinggi \\
\hline 7. & $\begin{array}{l}\text { Menurut Bapak/ } \\
\text { Ibu/Saudara(i), } \\
\text { apakah perusahaan } \\
\text { memberikan } \\
\text { kepuasan } \\
\text { penghargaan } \\
\text { kepada karyawan } \\
\text { yang mempunyai } \\
\text { prestasi yang baik? }\end{array}$ & Skor & 0 & 12 & 11 & 120 & 15 & 180 & 250 & 72 & Tinggi \\
\hline 8. & $\begin{array}{l}\text { Menurut Bapak/ } \\
\text { Ibu/Saudara(i), } \\
\text { sebagai karyawan } \\
\text { merasa puas dengan } \\
\text { adanya bonus } \\
\text { tambahan? }\end{array}$ & Skor & 0 & 24 & 21 & 20 & 55 & 180 & 250 & 72 & Tinggi \\
\hline 9. & $\begin{array}{l}\text { Menurut Bapak/ } \\
\text { Ibu/Saudara(i), } \\
\text { sebagai karyawan } \\
\text { apakah perusahan } \\
\text { memberikan } \\
\text { tunjangan THR } \\
\text { setiap tahunnya? }\end{array}$ & Skor & 0 & 10 & 13 & 76 & 65 & 190 & 250 & 76 & Tinggi \\
\hline 10 & $\begin{array}{lr}\text { Menurut } & \text { Bapak/ } \\
\text { Ibu/Saudara(i), } \\
\text { sebagai karyawan } \\
\text { sudah merasa puas } \\
\text { dengan } & \text { sistem } \\
\text { computer } & \text { yang } \\
\text { sekarang } & \text { ada } \\
\text { dikantor? } & \end{array}$ & Skor & 0 & 10 & 21 & 112 & 50 & 193 & 250 & 77,2 & Tinggi \\
\hline 11 & $\begin{array}{l}\text { Dalam } \\
\text { melaksanakan } \\
\text { semua tugas yang } \\
\text { dapat diselesaikan } \\
\text { melalui bimbingan } \\
\text { atasan memberikan } \\
\text { perasaan puas pada } \\
\text { diri bapak/Ibu? }\end{array}$ & Skor & 0 & 10 & 15 & 120 & 50 & 195 & 250 & 76,4 & Tinggi \\
\hline 12 & $\begin{array}{l}\text { Menurut Bapak/ } \\
\text { Ibu/Saudara(i), } \\
\text { apakah merasa puas } \\
\text { dengan sirkulasi } \\
\text { udara yang masuk } \\
\text { ditempat kerja? }\end{array}$ & Skor & 0 & 10 & 21 & 120 & 40 & 191 & 250 & 76,4 & Tinggi \\
\hline
\end{tabular}




\begin{tabular}{|c|c|c|c|c|c|c|c|c|c|c|c|}
\hline 13 & $\begin{array}{l}\text { Menurut } \text { Bapak/ } \\
\text { Ibu/Saudara(i), } \\
\text { sebagai karyawan } \\
\text { apakah sudah } \\
\text { merasa puas dengan } \\
\text { rekan kerja anda } \\
\text { sekarang? }\end{array}$ & Skor & 2 & 4 & 21 & 124 & 30 & 185 & 250 & 72 & Tinggi \\
\hline 14 & $\begin{array}{l}\text { Menurut Bapak/ } \\
\text { Ibu/Saudara(i), } \\
\text { sebagai karyawan } \\
\text { sudah merasa puas } \\
\text { dengan kemampuan } \\
\text { pimpinan dalam } \\
\text { menciptakan } \\
\text { hubungan kerja } \\
\text { yang } \\
\text { menyenangkan? }\end{array}$ & Skor & 0 & 4 & 10 & 24 & 12 & 194 & 250 & 77,6 & Tinggi \\
\hline 15 & $\begin{array}{l}\text { Menurut Bapak/ } \\
\text { Ibu/Saudara(i), } \\
\text { sebagai karyawan } \\
\text { sudah merasa puas } \\
\text { dengan ajakan } \\
\text { pimpinan untuk } \\
\text { berkomunikasi } \\
\text { dalam } \\
\text { menyelesaikan } \\
\text { tugas? }\end{array}$ & Skor & 0 & 4 & 21 & 144 & 25 & 194 & 250 & 77,6 & Tinggi \\
\hline 16 & $\begin{array}{lr}\text { Menurut } & \text { Bapak/ } \\
\text { Ibu/Saudara(i), } \\
\text { sebagai karyawan } \\
\text { apa sudah merasa } \\
\text { puas dengan } \\
\text { diberinya pelatihan } \\
\text { sesuai dengan } \\
\text { bidang pekerjaan, } \\
\text { agar lebih } \\
\text { mengembangkan } \\
\text { pengetahuaan yang } \\
\text { dimilikinya? }\end{array}$ & Skor & 0 & 4 & 24 & 124 & 45 & 197 & 250 & 78,8 & Tinggi \\
\hline 17 & $\begin{array}{l}\text { Menurut Bapak/ } \\
\text { Ibu/Saudara(i), } \\
\text { sebagai karyawan } \\
\text { apakah hubungan } \\
\text { antara pimpinan dan } \\
\text { sesama karyawan } \\
\text { terjalin dengan } \\
\text { harmonis? }\end{array}$ & Skor & 0 & 0 & 12 & 148 & 1 & 189 & 250 & 75,6 & Tinggi \\
\hline & Jumlah & & 11 & 158 & 501 & 1908 & 580 & 3158 & 4250 & 74,30 & Tinggi \\
\hline
\end{tabular}

Sumber: Data diolah, 2019

Berdasarkan tabel tersebut di atas, untuk mengetahui seberapa tinggi tingkat kepuasan kerja karyawan pada PT. Anugerah Fitrah Hidayah Makassar, maka digunakan rumus 
sebagaimana yang telah ditetapkan dalam metode analisis data pada pembahasan sebelumnya yaitu sebagai berikut:

Persentase=

$$
\begin{aligned}
& \frac{\text { Skor Aktual }}{\text { Skor Ideal } \times \text { Jumlah Kuisioner }} \times 100 \% \\
& =\frac{3158}{250 \times 17} \times 100 \% \\
& =\frac{3158}{4250} \times 100 \% \\
& \text { Persentase } \\
& =\mathbf{7 4 , 3 0 \%}
\end{aligned}
$$

Berdasarkan dari hasil analisis data di atas, diketahui bahwa tingkat kepuasan kerja karyawan pada PT. Anugerah Fitrah Hidayah Makassar sebagaimana dalam kriteria yang telah ditentukan sebelumnya dengan hasil yang telah dicapai yaitu sebesar $74,30 \%$ dengan interval $61 \%-80 \%$ tergolong dalam kriteria tinggi.

\section{KESIMPULAN}

Berdasarkan hasil analisis tingkat kepuasan kerja karyawan pada PT. Anugerah Fitrah Hidayah Makassar", maka dapat disimpulkan bahwa tingkat kepuasan kerja karyawan pada PT. Anugerah Fitrah Hidayah Makassar". Sebagaimana hasil yang telah dicapai yaitu sebesar $74,30 \%$ dengan interval $61 \%-80 \%$ tergolong dalam kriteria tinggi. Dengan demikian, maka hipotesis yang diajukan ditolak.

\section{SARAN}

Berdasarkan hasil kesimpulan yang telah dikemukakan di atas, maka disarankan kepada PT. Anugerah Fitrah Hidayah Makassar sekiranya dapat mempertahankan tingkat kepuasan kerja karyawan yang telah memenuhi kriteria tinggi dan lebih meningkatkan lagi dalam kriteria sangat tinggi, seperti memberikan bonus sesuai dengan usaha dan prestasi kerja karyawan, memberikan penghargaan atas hasil kerja karyawan, dan kemampuan pimpinan dalam menciptakan hubungan kerja yang menyenangkan serta bawahan tidak mengalami pertentangan dalam melaksanakan tugas karena adanya perlakuan yang membeda-bedakan dari pimpinan. Sehingga kepuasan kerja karyawan dapat lebih meningkat dan pada gilirannya tujuan organisasi dapat tercapai dengan optimal.

\section{DAFTAR PUSTAKA}

Sunyoto, 2013. Manajemen Sumber Daya Manusia, Cetakan kedua, CAPS (Center For Academic Publishing Service), Yogyakarta..

Herman dan Iwa, 2007. Perilaku Organisasi, Penerbit PT.Graha Ilmu, Yogyakarta.

Robbins, 2001. Manajemen, Edisi Tujuh,. Indeks Group Gramedia.

Hasibuan, 2012. Manajemen Sumber Daya Manusia, Edisi Enam Belas Bumi Aksara, Jakarta.

Kreitner dan Kinicki, 2005. Perilaku Organisasi, Edisi Lima, Penerbit Salemba Empat, Jakarta.

Martoyo, 2000. Manajemen Sumber Daya Manusia, BPFE, Jakarta.

Sutrisno, 2009. Manajemen Sumber Daya Manusia, Edisi Pertama, Kencana Prenada Media Group, Jakarta.

Rivai dan Sagala. 2009, Manajemen Sumber Daya Manusia untuk Perusahaan, Edisi dua, RajaGrafindo Persada, Jakarta.

Sugiyono, 2012. Metode Penelitian Kuantitatif Kualitatif dan R \& D. 